\title{
Mesophilous Quercus frainetto Dominated Forests from Western Balkans
}

\author{
Vladimir Stupar ${ }^{1 *}$
}

(1) University of Banja Luka, Faculty of Forestry, Department of Forest Ecology, Stepe Stepanovića 75A, BA-7800 Banja Luka, Bosnia and Herzegovina

* Correspondence: e-mail: vladimir.stupar@sf.unibl.org
Citation: Stupar V, 2020. Mesophilous Quercus frainetto Dominated Forests from Western Balkans. South-east Eur for 11(2): early view. https://doi. org/10.15177/seefor.20-15.

Received: 8 Sep 2020; Revised: 12 Oct 2020; Accepted: 12 Oct 2020; Published online: 10 Nov 2020

\section{ABSTRACT}

Hungarian oak (Quercus frainetto) has dominant or co-dominant role in many thermophilous deciduous forest communities in the Balkan Peninsula. However, recent field research in the north-western margin of its range has revealed that some stands have a pronounced mesophilous character, which was also supported by data from the literature. This paper aims to analyze this mesophilous community of Hungarian oak which is found in north-western Serbia, north-eastern Bosnia and Herzegovina (B\&H) and eastern Croatia. Numerical analysis, which included classification and ordination of all 474 available relevés of Hungarian oak forests from the western and central Balkans, along with the 43 relevés of mesophilous forests of oak-hornbeam from B\&H, have shown that 83 mesophilous Hungarian oak relevés are floristically and ecologically more similar to mesophilous forests of sessile oak-hornbeam (Erythronio-Carpinion) than to xero-thermophilous forests of Qeurcion confertae. The new association Carpino betuli-Quercetum frainetto ass. nova hoc loco was described, floristically and ecologically characterized and assigned to mesophilous oak-hornbeam forests of Erythronio-Carpinion. The study also discusses the syntaxonomical issues of Quercion confertae and its central association Quercetum frainetto-cerridis, considering the problem of the lack of good diagnostic species for both syntaxa, and introduces possible ways of dealing with these issues.
\end{abstract}

Keywords: Carpino betuli-Quercetum frainetto; Erythronio-Carpinion; forest vegetation; Hungarian oak; Italian oak; Quercetum frainetto-cerridis; Quercion confertae

\section{INTRODUCTION}

Hungarian oak (Quercus frainetto) is a subendemic south European tree species with a relatively small distribution area that is confined to central, eastern and southern Balkans from where it extends to western Anatolia, western Balkans (Bosnia and Herzegovina, hereafter B\&H, Montenegro and Croatia), western Romania and eastern Hungary, with a disjunction in Italy. It either functions as the main or a subordinated element of xero-thermophilous forests of Quercetalia pubescenti-petraeae (Jovanović et al. 1986, Stefanović 1988, Kojić et al. 1998, Bergmeier and Dimopoulos 2008, Borhidi et al. 2012, Vukelić 2012, Tomić and Rakonjac 2013, Indreica 2015, Škvorc et al. 2017, Di Pietro et al. 2019, Tzonev et al. 2019). In the Balkan part of the distribution area, its communities are mainly assigned to Quercion confertae, with a few communities from Bulgaria classified in Quercion petraeo-cerridis (Tzonev et al. 2019). It is also traditionally accepted that it builds a zonal vegetation in lowland and hilly regions with the dryer sub-continental climate of central Balkans (Horvat et al. 1974).

However, recent field research of these communities in the north-eastern $B \& H$ has suggested that there are mesophilous stands of Hungarian oak dominated forests that share more floristic and ecological features with mesophilous Erythronio-Carpinion than with xero-thermophilous Quercion confertae. These findings were supported by the classification of the thermophilous deciduous forests of Western Balkans (Stupar et al. 2016), where a fairly homogenous group of relevés, with distinct mesophilous character, traditionally assigned to Quercion confertae, i.e. Quercetum frainetto-cerridis, remained unclassified after semi-supervised classification. These were the relevés from the north-western margin of the range of Hungarian oak: eastern Croatia, north-eastern B\&H and northwestern Serbia, the area with more temperate sub-oceanic 
macroclimatic conditions where Erythronio-Carpinion takes over as a climatogenic community. Mesophilous character of these stands has already been pointed out in the past (Vukićević 1959, Glišić 1968, Fukarek et al. 1974, Stefanović 1988, Trinajstić et al. 1996), but was never elaborated outside of the scope of thermophilous forests.

Additionally, the lack of good diagnostic species for Quercetum frainetto-cerridis, the central association of continental Quercion confertae, have been reported (Stupar et al. 2016, Tzonev et al. 2019). Moreover, Stupar et al. (2015) and Tzonev et al. (2019) stress out the floristic heterogeneity and polymorphism of this most widespread deciduous oak association in continental northern-central Balkans. With recent initiatives to split Balkan Hungarian oak communities into two vicariant alliances, the one of southern and the other one of central Balkan distribution (Mucina et al. 2016, Di Pietro et al. 2019), syntaxonomy of the Balkan Hungarian oak communities is on the way to be revised.

The principal aims of this paper are the following: i) to analyze all available relevés of Hungarian oak dominated forests in the western and central Balkans in order to ecologically and floristically delineate mesophilous from xerothermophilous stands, ii) to reveal floristic and ecological relationships of mesophilous Hungarian oak stands to the mesophilous Erythronio-Carpinion, iii) to describe the new mesophilous community dominated by Hungarian oak, and iv) to tackle syntaxonomical issues inside the Hungarian oak communities of western and central Balkans.

\section{MATERIALS AND METHODS}

\section{Study Area}

The study was conducted in a distribution area of the Hungarian oak in the western and central Balkans. This included Serbia and North Macedonia as well as eastern parts of B\&H and Croatia (Figure 1). Biogeographically, the study area belongs to (a) the Euro-Siberian biogeographical region, particularly the Illyrian, Pindan and Bulgarian sectors of the Apennine-Balkan province, and the Pannonian sector of the Pannonian-Carpathian province, and (b) the Mediterranean biogeographical region, particularly the Attico-Thessalio-Macedonian sector of the GraecoAegean province (Rivas-Martínez et al. 2004). The climate of the major part of the area investigated is continental with dry and hot summers and cold winters and annual precipitation of 550-700 mm (Delijanić et al. 1964). Towards the west, the climate is modified by increased maritime influence, resulting in annual precipitation above 700 $\mathrm{mm}$. Topographically and geologically, the region is mainly characterized by hills and low mountains on mainly siliceous bedrock and tertiary sediments (Velić and Velić 1983). From the bioclimatic point of view, the majority of Serbia and North Macedonia and eastern parts of B\&H are inside "Quercion frainetto" bioclimatic zone, while north-eastern B\&H, north-western Serbia and part of eastern Croatia with Hungarian oak stands (Krndija Mt) belong to "Carpinion betuli illyricum" zone (Horvat et al. 1974).

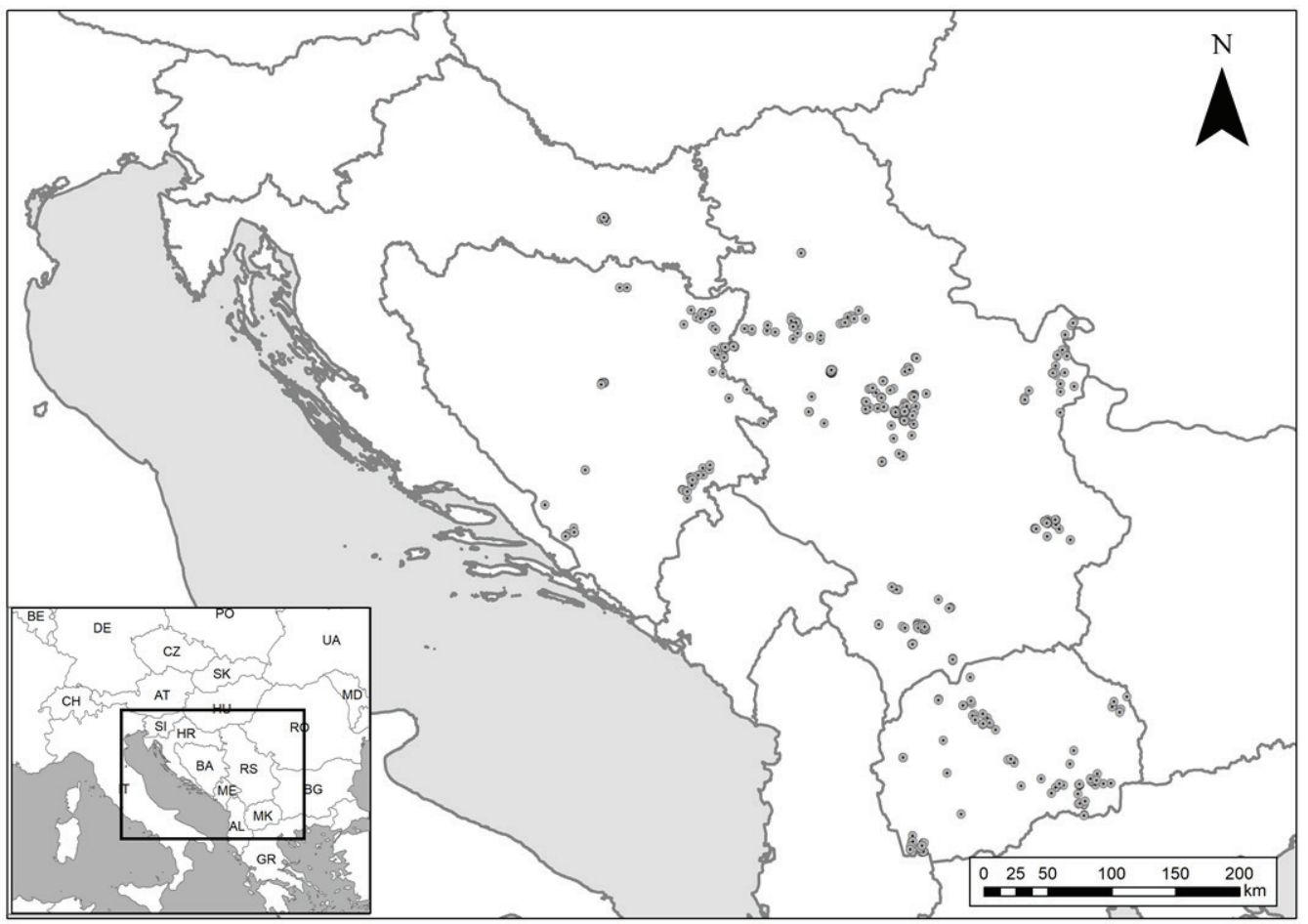

Figure 1. Location of the study area. Dots represent localities of 474 relevés of Hungarian oak dominated forests used in this study. 


\section{Data Collection and Analysis}

The study was based on a dataset consisting of 504 relevés of Hungarian oak dominated forests from Bosnia and Herzegovina (69), Croatia (14), Serbia (296), and North Macedonia (125) (Figure 1). The majority of relevés were acquired from the literature (see Supplementary File 1), while 23 relevés were recently collected in the field in $\mathrm{B} \& \mathrm{H}$. After an initial inspection of the dataset, 30 relevés of the unpublished Carici cuspidatae-Quercetum frainetto from North Macedonia (Rizovski 1972) were omitted because of their conspicuous transitional character between Carpinion orientalis, Quercion confertae and AremonioFagion. All published relevés were initially or by the later overviews subordinated to Quercion confertae. Only 26 relevés of Carpino orientalis-Quercetum frainetto (Rizovski 1978) Matevski et al. 2008 were originally classified inside Carpinion orientalis (Rizovski 1972), but the association was reassigned to Quercion confertae upon validation by Matevski et al. (2008).

Besides, to compare this dataset to the mesophilous oak-hornbeam forests of Erythronio-Carpinion, we also collected 43 relevés of oak-hornbeam forests in $\mathrm{B} \& \mathrm{H}$, from the available literature (see Supplementary File 1), as well as in the field.

All relevés were made using the standard Central European phytosociological method (Braun-Blanquet 1964) with Braun-Blanquet scale cover-abundance estimates of each species. The final dataset of 517 relevés was entered into the Turboveg database (Hennekens and Schaminée 2001) and then exported into JUICE software (Tichý 2002) for further analysis.

Before numerical analysis the following data adjustments were made. Mosses were excluded from the dataset, as they were not recorded by all authors. All layers were merged into a single layer to take account of inconsistent sampling in the relevés from literature. Records of species determined on the genus level were deleted. Quercus daleschampi was treated as Q. petraea, Fagus moesiaca as F. sylvatica, while Lathyrus vernus and $L$. venetus were combined. Taxa from taxonomically critical groups that were not always identified by the relevé authors and species that included several subspecies that were not always recorded or recognized by authors were also combined into aggregates (Bromus erectus agg., Carex muricata agg. and Festuca pseudovina agg.).

The numerical analysis was performed in R software, version 3.4.1 (The R Foundation for Statistical Computing 2017). Classification of the data set was done using Ward's method and Manhattan distance measure, with coverabundance estimates transformed to presence/absence. We stopped further division at the level of six clusters because this was the level where mesophilous sessile oak-hornbeam relevés were separated as an individual cluster. Diagnostic species for clusters were determined using species fidelity measure (phi value) (Chytrý et al. 2002) in the JUICE software. We also calculated Fischer's exact test and gave a zero phi value to a species with $P>0.001$. The threshold phi value for the species to be considered as a diagnostic was set at 0.20 .
To extract the main gradients in species composition, all 517 relevés, together with the selected ecological variables were projected onto the two-dimensional ordination space of DCA (detrended correspondence analysis). Species' ecological indicator values (EIVs) for temperature, light, moisture, continentality, soil reaction, and nutrients (Pignatti et al. 2005) were used as explanatory ecological variables. Unweighted average EIVs were calculated in JUICE and passively projected onto a DCA plot. The significance of their correlation with the DCA relevé scores was tested using the modified permutation test proposed by Zelený and Schaffers (2012).

Plant nomenclature followed Euro+Med (2006). Syntaxonomical concepts and nomenclature of higher syntaxa followed Mucina et al. (2016). The description of new syntaxon followed the rules of ICPN (Theurillat et al. 2020).

\section{RESULTS}

\section{Classification and Ordination}

Numerical analysis of relevés included in the initial dataset yielded six ecologically and floristically distinct clusters arranged in three groups with clearly defined diagnostic species (Table 1, Figure 2): group A (clusters 1 and 2 ), group B (clusters 3, 4 and 5) and group C (cluster 6).

Mesophilous relevés dominated by Quercus frainetto (cluster 2) were classified together with the mesophilous relevés of oak-hornbeam forests of Erythronio-Carpinion (cluster 1). Figure 2 shows that the separation of these two clusters inside group A happened at a lower level than the separation of five clusters of xero-thermophilous Hungarian oak relevés (cluster groups $B$ and $C$ ). Mesophilous relevés from the literature that were classified inside this group are mainly those that were originally assigned to Quercetum frainetto-cerridis (Rudski 1949) Trinajstić et al. 1996 carpinetosum betuli Rudski 1949 or Quercetum frainetto-cerridis ruscetosum aculeati Jovanović et Dunjić 1951. However, relevés from the original diagnosis of the subassociation carpinetosum betuli of Quercetum frainettocerridis (Rudski 1949) were classified to cluster 4.

Species diagnostic for group A are those characteristic for the mesophilous forests of Erythronio-Carpinion and Fagetalia sylvaticae: Carpinus betulus, Carex pilosa, Stellaria holostea, Epimedium alpinum, Pulmonaria officinalis, Galium sylvaticum etc. Cluster 1 is differentiated by acidophilous Pteridium aquilinum, Luzula luzuloides and Melampyrum pratense along with the mesophilous Cruciata glabra, Tilia cordata and Drymochloa drymeja. On the other hand, cluster 2 is differentiated by the mesotermic Ligustrum vulgare and Tilia tomentosa and also some humidity indicators: Ulmus minor, Hedera helix, Lonicera caprifolium, Cornus sanguinea, Euonymus europaeus, etc. which are all common in oak-hornbeam forests of the southern margin of Pannonian plane in B\&H and Croatia.

Group B represents the relevés traditionally assigned to Quercion confertae (Table 1, columns 3-5). Diagnostic species are widespread thermophilous species like Trifolium 


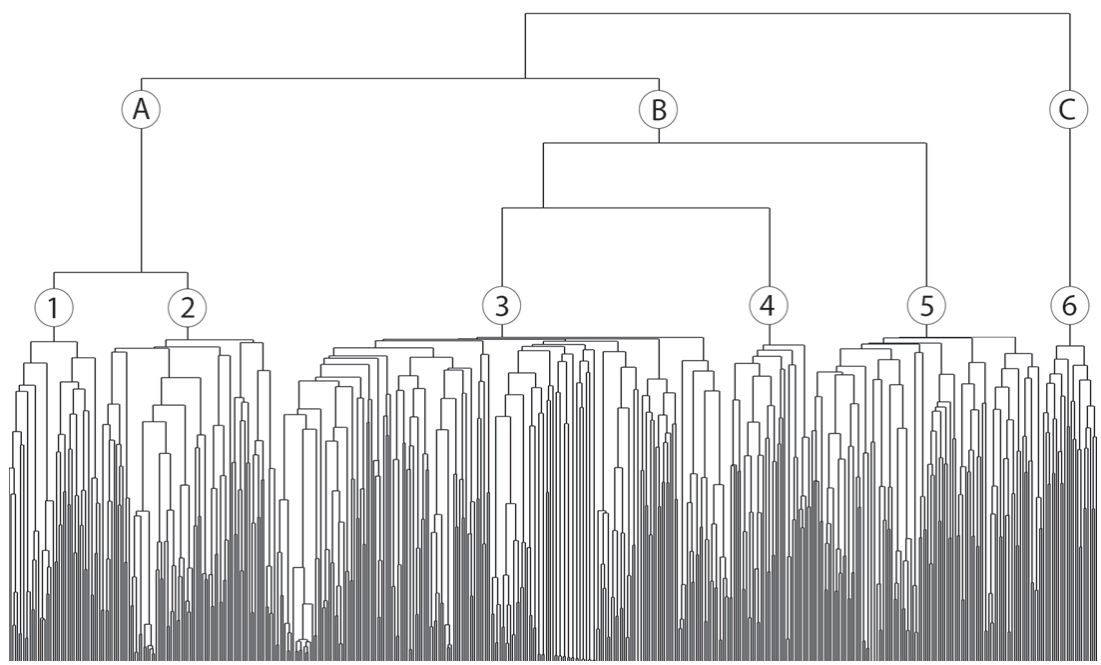

Figure 2. Classification of Hungarian oak relevés in western and central Balkans. Groups: A - Erythronio-Carpinion, B - Quercion confertae, $\mathrm{C}$-Carpinion orientalis. Cluster numbers correspond to those used in Table 1, Figure 3 and throughout the text.

Table 1. Synoptic table of Hungarian oak communities in western and central Balkans. Frequencies of species are presented as percentages, with phi values multiplied by 100 shown in superscript. Diagnostic species (phi values higher than 0.20 ) for each cluster are shaded (only ten species with the highest phi value are presented). Cluster numbers correspond to those used throughout the text. Full version of the table is in Supplementary File 2.

\begin{tabular}{|c|c|c|c|c|c|c|c|c|c|}
\hline \multirow{2}{*}{$\begin{array}{l}\text { Cluster group } \\
\text { Cluster number }\end{array}$} & \multicolumn{4}{|c|}{ A } & \multicolumn{4}{|c|}{ B } & \multirow{2}{*}{$\frac{C}{6}$} \\
\hline & \multicolumn{2}{|l|}{1} & \multicolumn{2}{|l|}{2} & 3 & \multicolumn{2}{|c|}{4} & 5 & \\
\hline No. of relevés & 44 & & 83 & & 215 & 39 & & 110 & 26 \\
\hline Avg. no. of species & 31 & & 36 & & 31 & 44 & & 39 & 53 \\
\hline \multicolumn{10}{|l|}{ Cluster 1} \\
\hline Pteridium aquilinum & 77 & 67 & \multicolumn{2}{|l|}{4} & 14 & \multicolumn{2}{|c|}{. } & 17 & . \\
\hline Cruciata glabra & 70 & 51.7 & \multicolumn{2}{|l|}{11} & 12 & \multicolumn{3}{|c|}{$41 \quad 20.1$} & . \\
\hline Luzula luzuloides & 41 & 57.4 & \multicolumn{2}{|l|}{2} & 1 & \multicolumn{2}{|c|}{. } & . & . \\
\hline Melampyrum pratense & 50 & 56.5 & \multicolumn{2}{|l|}{10} & 5 & \multicolumn{2}{|l|}{. } & . & . \\
\hline Fagus sylvatica & 55 & 55.3 & \multicolumn{2}{|l|}{12} & 5 & \multicolumn{2}{|l|}{3} & 4 & . \\
\hline Tilia cordata & 36 & 55.1 & \multicolumn{2}{|l|}{1} & 1 & \multicolumn{2}{|l|}{. } & . & . \\
\hline Drymochloa drymeja & 27 & 48.2 & \multicolumn{2}{|l|}{. } & 1 & \multicolumn{2}{|l|}{. } & . & . \\
\hline Corylus avellana & 57 & 48.2 & \multicolumn{2}{|l|}{11} & 7 & \multicolumn{2}{|l|}{10} & 15 & . \\
\hline Quercus petraea & 98 & 44.2 & \multicolumn{2}{|l|}{40} & 31 & \multicolumn{2}{|l|}{44} & 40 & 38 \\
\hline Erythronium dens-canis & 23 & 42.6 & \multicolumn{2}{|l|}{. } & 1 & \multicolumn{3}{|l|}{. } & . \\
\hline \multicolumn{10}{|l|}{ Cluster 2} \\
\hline Ligustrum vulgare & 16 & & 82 & 51.1 & 23 & 31 & & 7 & 19 \\
\hline Hedera helix & 11 & & 49 & 44.3 & 8 & 3 & & . & 15 \\
\hline Tilia tomentosa & 18 & & 45 & 39.3 & 7 & 13 & & 2 & . \\
\hline Ulmus minor & 5 & & 40 & 37.6 & 10 & 13 & & 6 & . \\
\hline Euonymus europaeus & . & & 29 & 35 & 7 & 8 & & 4 & . \\
\hline Lonicera caprifolium & 5 & & 42 & 34.4 & 6 & 18 & & 18 & . \\
\hline Cornus sanguinea & 18 & & 45 & 33.5 & 7 & 31 & & . & . \\
\hline Acer campestre & 59 & & 94 & 33.5 & 47 & 77 & & 41 & 23 \\
\hline Polygonatum multiflorum & 18 & & 27 & 32.2 & 1 & . & & . & . \\
\hline Galeopsis pubescens & 5 & & 16 & 30.5 & . & . & & . & . \\
\hline
\end{tabular}


Table 1. (continuation) Synoptic table of Hungarian oak communities in western and central Balkans. Frequencies of species are presented as percentages, with phi values multiplied by 100 shown in superscript. Diagnostic species (phi values higher than 0.20 ) for each cluster are shaded (only ten species with the highest phi value are presented). Cluster numbers correspond to those used throughout the text. Full version of the table is in Supplementary File 2.

\begin{tabular}{lrr|rrrr|r}
\hline Cluster group & \multicolumn{3}{c}{ A } & \multicolumn{1}{c}{ B } & \multicolumn{1}{c}{ C } \\
\cline { 2 - 8 } Cluster number & 1 & 2 & 3 & 39 & 110 & 6 \\
\hline No. of relevés & 44 & 83 & 215 & 31 & 44 & 39 & 26 \\
Avg. no. of species & 31 & 36 & & & 53 \\
\hline
\end{tabular}

\section{Cluster 3}

Dianthus armeria

Trifolium arvense

Stachys germanica

Cytisus austriacus

Hypericum perforatum

Chrysopogon gryllus

Aira elegantissima

Trifolium campestre

Rosa tomentosa

Scleranthus annuus

\begin{tabular}{|c|c|c|c|c|}
\hline & . & 12 & 32.1 & . \\
\hline . & . & 13 & 31 & . \\
\hline · & . & 10 & 29.5 & . \\
\hline . & . & 10 & 27.7 & . \\
\hline 7 & 10 & 39 & 24.7 & 10 \\
\hline . & . & 10 & 24.3 & 3 \\
\hline . & . & 9 & 22 & . \\
\hline . & 1 & 8 & 21.8 & . \\
\hline . & . & 6 & 21.7 & . \\
\hline . & . & 6 & 21.7 & . \\
\hline
\end{tabular}

\begin{tabular}{l} 
Cluster 4 \\
Viburnum lantana \\
Carex tomentosa \\
Taraxacum officinale \\
Inula hirta \\
Peucedanum cervaria \\
Ulmus glabra \\
Polygonatum odoratum \\
Iris graminea \\
Vincetoxicum hirundinaria \\
Hieracium umbellatum \\
\hline Cluster 5 \\
Stachys scardica \\
Paramoltkia doerfleri \\
Eryngium palmatum \\
Lembotropis nigricans \\
Helleborus odorus ssp. cyclophyllus \\
Verbascum glabratum \\
Origanum vulgare \\
Corydalis solida \\
Cirsium vulgare \\
Verbascum nigrum
\end{tabular}

Verbascum nigrum

$\begin{array}{rrrrrr}. & 11 & 21 & 77 & 67.9 & 1 \\ . & . & 1 & 46 & 63.3 & \\ . & . & 4 & 38 & 55 & \\ . & . & 8 & 44 & 54.9 & 1 \\ . & 4 & 1 & 33 & 50.1 & \\ 2 & 1 & 2 & 33 & 49 & \\ . & 4 & 2 & 41 & 47.3 & 12 \\ . & . & 28 & 45.7 & 4 \\ 2 & 1 & 18 & 44 & 43.2 & 7 \\ 11 & . & 3 & 28 & 34.5 & 4\end{array}$

\section{Cluster 6}

Achnatherum bromoides

Crocus chrysanthus

Cardamine graeca

Asparagus acutifolius

Acer monspessulanum

Silene italica

Carpinus orientalis

11

10

1

15

1

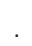

1

12

4$$
4
$$

$\begin{array}{rrr}. & . & . \\ . & . & . \\ . & . & . \\ 11 & 10 & 3 \\ . & . & \cdot \\ . & . & . \\ . & 2 & 6 \\ . & . & . \\ . & . & . \\ . & 1 & 9\end{array}$

\begin{tabular}{l|ll|l}
\hline & 55 & 60.5 & 15 \\
. & 18 & 39.5 & $\cdot$ \\
. & 18 & 39.5 & $\cdot$ \\
3 & 36 & 37.9 & $\cdot$ \\
. & 16 & 37.4 & $\cdot$ \\
. & 13 & 32.9 &. \\
. & 20 & 32.1 & $\cdot$ \\
. & 10 & 29.1 & $\cdot$ \\
. & 10 & 29.1 &. \\
. & 18 & 28.5 &. \\
\hline
\end{tabular}

Carex muricata agg.

2

Juniperus oxycedrus

$\begin{array}{lrr}\cdot & & \\ \cdot & \cdot & \\ \cdot & \cdot & 2 \\ . & \cdot & 1 \\ . & \cdot & 6 \\ . & 6 & 33 \\ . & 11 & 7 \\ 2 & 12 & 7 \\ . & \cdot & \end{array}$

(1)

\begin{tabular}{rrrrr}
. & & & 81 & 88.2 \\
. & $\cdot$ & 77 & 85.7 \\
. & $\cdot$ & 73 & 83.3 \\
2 & $\cdot$ & 69 & 79.1 \\
1 & $\cdot$ & 65 & 75.8 \\
6 & $\cdot$ & 77 & 70.6 \\
33 & $\cdot$ & 15 & 100 & 67 \\
7 & 21 & 20 & 73 & 66.2 \\
7 & 3 & 6 & 65 & 63.1 \\
\hline
\end{tabular}


Table 1. (continuation) Synoptic table of Hungarian oak communities in western and central Balkans. Frequencies of species are presented as percentages, with phi values multiplied by 100 shown in superscript. Diagnostic species (phi values higher than 0.20 ) for each cluster are shaded (only ten species with the highest phi value are presented). Cluster numbers correspond to those used throughout the text. Full version of the table is in Supplementary File 2.

\begin{tabular}{|c|c|c|c|c|c|c|}
\hline \multirow{2}{*}{$\begin{array}{l}\text { Cluster group } \\
\text { Cluster number }\end{array}$} & \multicolumn{2}{|c|}{ A } & \multicolumn{3}{|c|}{ B } & \multirow{2}{*}{$\begin{array}{l}C \\
6\end{array}$} \\
\hline & 1 & 2 & 3 & 4 & 5 & \\
\hline No. of relevés & 44 & 83 & 215 & 39 & 110 & 26 \\
\hline Avg. no. of species & 31 & 36 & 31 & 44 & 39 & 53 \\
\hline
\end{tabular}

\section{Erythronio-Carpinion}

Carpinus betulus

Carex pilosa

Stellaria holostea

Epimedium alpinum

Rubus hirtus

Pulmonaria officinalis

Galium sylvaticum

Carex sylvatica

Prunus avium

Helleborus odorus

\begin{tabular}{llll|l}
98 & 49.7 & 94 & 46.3 & 23 \\
36 & 39.2 & 20 & 15.6 & \\
48 & 38.2 & 30 & 16.8 & \\
32 & 34.1 & 20 & 16.8 \\
52 & 33.5 & 48 & 29 & \\
25 & 27.1 & 23 & 23.7 & \\
27 & 23.9 & 25 & 21 & \\
18 & 22.9 & 13 & 13.6 & \\
68 & 35.6 & 49 & 17.5 & \\
39 & & 64 & 20.8 & 47
\end{tabular}

23

8

1

2

11

47

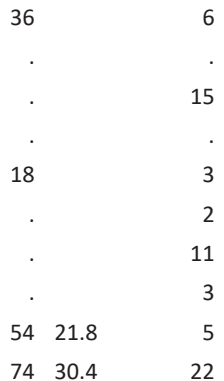

\section{Quercion confertae}

Galium pseudaristatum

Euphorbia cyparissias

Astragalus glycyphyllos

Melittis melissophyllum

Trifolium alpestre

Cytisus hirsutus

Inula salicina

$\begin{array}{rr}\cdot & 27 \\ 5 & 11 \\ 2 & 18 \\ 16 & 18 \\ \cdot & 1 \\ 18 & 17 \\ . & 1 \\ . & 10\end{array}$

4

$\begin{array}{rrrrrr}19 & 44 & 37 & 17.9 & . \\ 41 & 16.6 & 67 & 42.6 & 28 & \\ 8 & 33 & 27 & 15.7 & . \\ 7 & 36 & 39 & 22.3 & . \\ 15 & 46 & 34.2 & 34 & 19.4 & 8 \\ 27 & 51 & 25.8 & 35 & & 8 \\ 7 & 21 & 35 & 29.7 & 12 \\ 29 & 10 & 55 & 41 & 12\end{array}$

\section{Quercion confertae + Carpinion orientalis}

Tanacetum corymbosum

Festuca heterophylla

. 10

Silene viridiflora

Physospermum cornubiense

Sorbus domestica

Festuca pseudovina agg.

Lathyrus niger

Lathyrus laxiflorus

Trifolium pignantii

Luzula forsteri

(25

\section{8}

43

25

35

23

$44 \quad 12.2$

31

3

1

12

Other species with high frequency

Quercus cerris

Quercus frainetto

Sorbus torminalis

Acer tataricum

Crataegus monogyna

Fraxinus ornus

Dactylis glomerata

Veronica chamaedrys

Tamus communis

Lathyrus venetus + vernus

$\begin{array}{rr}20 & 9 \\ 2 & 10 \\ 43 & 33 \\ 57 & 89 \\ 64 & 9 \\ 43 & 7 \\ 18 & 5 \\ 50 & 5 \\ 9 & 5 \\ 30 & 4\end{array}$

$\begin{array}{rr}94 & 90 \\ 100 & 100 \\ 33 & 30 \\ 89 & 17 \\ 94 & 67 \\ 76 & 6 \\ 55 & 4 \\ 54 & 39 \\ 52 & 12 \\ 47 & 2\end{array}$

$\begin{array}{rr}90 & 100 \\ 100 & 100 \\ 30 & 62 \\ 17 & 72 \\ 67 & 97 \\ 60 & 54 \\ 46 & 46 \\ 39 & 49 \\ 12 & 49 \\ 20 & 2\end{array}$

\begin{tabular}{lllllll}
87 & 50.2 & 39 & 4.8 & 50 & \\
64 & 67 & 24.9 & 35 & \\
44 & & 45 & 18.7 & 46 & \\
82 & 31.6 & 79 & 28.9 & 62 & \\
56 & 16.4 & 41 & 88 & 45.8 \\
62 & 28.9 & 10 & & 62 & 28.9 \\
90 & 32.9 & 73 & 17.7 & 85 & 28.3 \\
. & 63 & 39.9 & 81 & 58.7 \\
. & 48 & 36.8 & 54 & 43.5 \\
5 & 59 & 27.1 & 85 & 51.8 \\
\hline
\end{tabular}

$\begin{array}{rrr}100 & 88 & 8 \\ 100 & 100 & 100 \\ 62 & 40 & 46 \\ 72 & 35 & \\ 97 & 68 & 31 \\ 54 & 41 & 96 \\ 46 & 87 & 96 \\ 49 & 81 & 100 \\ 49 & 17 & 46 \\ 21 & 50 & 27\end{array}$


alpestre, Euphorbia cyparissias, Silene coronaria, Tanacetum corymbosum, Festuca heterophylla, Silene viridiflora, Sorbus domestica, Festuca pseudovina agg. and Lathyrus niger, with only two species of the Balkan significance: Galium pseudaristatum and Physospermum cornubiense.

Cluster 3 (Table 1, column 3 ) is composed of the largest number of relevés (215). It encompasses the majority of the relevés assigned to Quercetum frainetto-cerridis and Quercetum frainetto Jovanović et al. 1982 nom. inval. (Art. 5) from Central Serbia and eastern B\&H with only several relevés from North Macedonia and Croatia. It is poorly differentiated from the rest of the dataset due to the lack of diagnostic species, a low cover of herb layer (there are no species in the herb layer with the cover of $5 \%$ or more), and overall poor floristic composition with the smallest average number of species per relevé (31) among thermophilous clusters. Diagnostic species indicate poor nutrition, open canopy and structural degradation: Aira elegantissima, Hypericum perforatum, Stachys germanica, Stachys recta, Thymus pulegioides, Trifolium arvense, Trifolium campestre etc. Species diagnostic for Quercion confertae only appear with the low frequency.

Cluster 4 (Table 1, column 4) comprises relevés from Serbia which are found on more nutritious soils, and although there is less light due to closed canopy, there appear many more species per relevé (44) when compared to cluster 3. Diagnostic species are mainly thermophilous: Viburnum lantana, Carex tomentosa, Inula hirta, Polygonatum odoratum, Iris graminea, Vincetoxicum hrundinaria etc. This cluster mainly encompasses relevés from the original diagnosis of Quercetum frainetto-cerridis (Rudski 1949) Trinajstić et al. 1996 made by Rudski (1949), which also includes the original diagnosis of the subassociation carpinetosum betuli Rudski 1949. Our results also suggest that this is the central and typical cluster of the zonal Quercion confertae in Central Serbia, also known as "Quercetum frainetto-cerris moesiacum" (Horvat et al. 1974).

Cluster 5 encompasses relevés from North Macedonia and Kosovo and Metohija and represents the southern variant of central Balkan Hungarian oak forests. It encompasses relevés mainly assigned to Quercetum frainetto-cerridis macedonicum Horvat 1959 nom. illeg. (Art 34a) and Quercetum frainetto-cerridis scardicum Krasniqi 1972 nom. inval. (Art 3b). Diagnostic species besides those of Quercion confertae are Balkan elements: Stachys scardica, Paramoltkia doerfleri, Eryngium palmatum, as well as Lathyrus laxiflorus and Trifolium pignantii (which are shared with cluster 6).
In the sense of Horvat et al. (1974), this cluster stands for zonal association of North Macedonia and northern Greece "Quercetum frainetto-cerris macedonicum".

Cluster 6 is represented by the association Carpino orientalis-Quercetum frainetto (Rizovski 1978) Matevski et al. 2008, which is found in southern North Macedonia, and although recently validated and assigned to Quercion confertae (Matevski et al. 2008), this association was originally classified within Carpinion orientalis (Rizovski 1972). Our results support the latter concept, considering that diagnostic species of this cluster are mainly related to Carpinion orientalis: Achnatherum bromoides, Asparagus acutifolius, Carex halleriana, Carpinus orientalis, Lonicera etrusca, etc. (Table 1, column 6). Furthermore, although cluster 6 and cluster group B both belong to xero-thermophilous forests of the class Quercetea pubescentis, cluster 6 was the first to separate from the rest of the dataset (Figure 2), which is probably because Carpinion orientalis in relation to Quercion confertae includes many more thermophilous species, while on the other hand, Quercion confertae harbors a larger number of the widespread nemoral mesophytes.

Classification is backed by the DCA ordination plot (Figure 3), where EIVs for temperature, moisture, light and nutrients are significantly related to the first two DCA axes $(P<=0.001$; Table 2). The main ecological factors influencing the variation in the floristic composition are EIVs for temperature (positively correlated to the first axis) and moisture (negatively correlated with the first axis), suggesting that the first axis represents the macro-climatic gradient that runs from mesophilous forests of Erythronio-Carpinion (left side of the diagram) to xerothermophilous forests of Quercion confertae (center of the diagram) and Carpinion orientalis (right side of the diagram).

The present analysis suggests that group A stands for mesophilous Erythronio-Carpinion, group B belongs to Quercion confertae, while group C (cluster 6) represents the most xero-thermophilous Carpinion orientalis. Cluster 2 is recognized as the new mesophilous association of Hungarian oak that belongs to Erythronio-Carpinion. Syntaxonomical scheme of the new association is as follows:

\section{Carpino-Fagetea sylvaticae Jakucs ex Passarge 1968}

Carpinetalia betuli P. Fukarek 1968

Erythronio-Carpinion (Horvat 1958) Marinček in Wallnöfer et al. 1993

Carpino betuli-Quercetum frainetto ass. nova hoc loco (Table 1 column 2, Table 3)

Table 2. Relationship between the first two DCA axes and mean EIVs calculated using modified permutation test. $P$ values are based on 999 permutations. DCA1 and DCA2 are normalized regression coefficients for the first and second DCA axis, respectively. $R^{2}$ is a coefficient of determination.

\begin{tabular}{lllll}
\hline & DCA1 & DCA2 & $\mathbf{R}^{2}$ & P \\
\hline Light & 0.616 & 0.788 & 0.583 & $\mathbf{0 . 0 0 1}$ \\
Temperature & 0.996 & 0.090 & 0.442 & $\mathbf{0 . 0 0 1}$ \\
Continentality & 0.889 & -0.457 & 0.129 & $\mathbf{0 . 1 8 5}$ \\
Moisture & -0.789 & -0.614 & 0.677 & $\mathbf{0 . 0 0 1}$ \\
Soil reaction & -0.164 & -0.987 & 0.154 & $\mathbf{0 . 1 2 4}$ \\
Nutrients & -0.581 & -0.814 & 0.622 & $\mathbf{0 . 0 0 1}$ \\
\hline
\end{tabular}




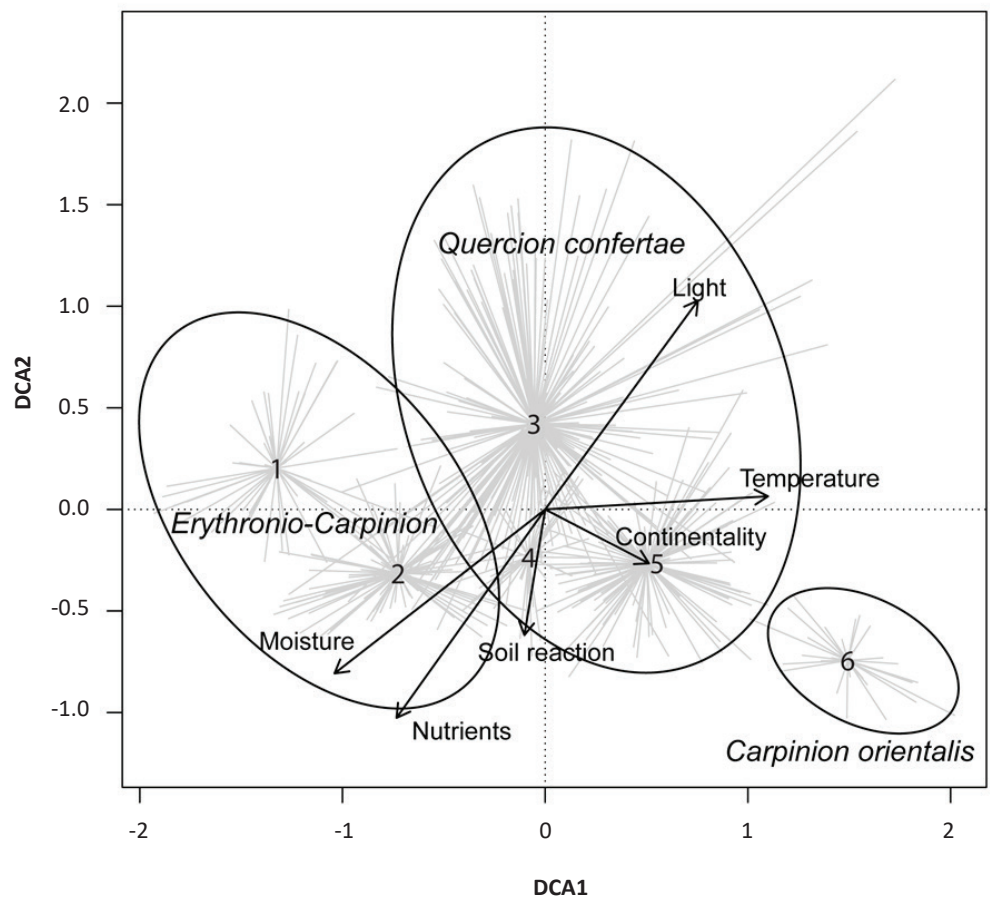

Figure 3. DCA spider plot of 517 classified relevés of the Hungarian oak dominated communities in western and central Balkans with EIVs passively projected. Centroids of clusters are indicated by numbers corresponding to Table 1 , Figure 2 , and to cluster numbers used in the text.

\section{Description of the New Syntaxon}

Carpino betuli-Quercetum frainetto ass. nova hoc loco (Table 1, column 2)

Typus: Table 3, rel. 4 - holotypus hoc loco

Stands of this association are mainly high forests sometimes structurally degraded with closed canopy (80$100 \%$ ) and of height between 20 and $30 \mathrm{~m}$ (Figure 4). They are found in north-eastern B\&H, north-western Serbia and eastern Croatia (Figure 5), on predominantly mild slopes and elevations up to $200 \mathrm{~m}$ a.s.l. They thrive on deep dystric cambisols or luvisols, mainly upon tertiary clayey lake sediments.

The dominant species of the canopy layer is Quercus frainetto, often accompanied by Quercus cerris, while Carpinus betulus is the dominant species of the understory. The shrub layer is rich in mesophilous species: Acer tataricum, Acer campestre, Crataegus monogyna, Prunus avium, Rubus hirtus, Cornus sanguinea, Pyrus pyraster, Euonymus europaeus, Ruscus hypoglossum and Hedera helix with some thermophilous and sub-thermophilous elements: Fraxinus ornus, Ligustrum vulgare, Rosa arvensis, Ruscus aculeatus and Tilia tomentosa. Due to the closed canopy, the herb layer is not so rich, but the species of Erythronio-Carpinion such as Tamus communis, Helleborus odorus, Epimedium alpinum, Galium schultesii and other species of mesophilous deciduous forests (Fagetalia sylvaticae) such as Cruciata glabra, Dactylis glomerata, Polygonatum multiflorum, Symphytum tuberosum, Viola reichenbachiana, Carex sylvatica,
Brachypodium sylvaticum, and Veronica chamaedrys prevail. Thermophilous elements are much less frequent and include: Viola hirta, Melittis melisophyllum, Potentilla micrantha, Festuca heterophylla etc. (all besides V. hirta with under 50\% of frequency).

The published relevés of this association were originally mainly assigned to Quercetum frainetto-cerridis (Rudski 1949) Trinajstić et al. 1996 carpinetosum betuli Rudski 1949 (Vukićević 1959, Glišić 1968, Trinajstić et al. 1996, Stajić et al. 2008) and Quercetum frainetto-cerridis ruscetosum aculeati Jovanović et Dunjić 1951 (Jovanović and Dunjić 1951, Vukićević 1959, Glišić 1968) or were not assigned to any subassociation of Quercetum frainetto-cerridis (Fukarek et al. 1974).

However, it should be emphasized that relevés from the original diagnosis of the subassociation carpinetosum betuli of Quercetum frainetto-cerridis (Rudski 1949) do not belong to this association as they were classified in cluster 4 together with other thermophilous relevés of typical Quercetum frainetto-cerridis. So, as far as our results suggest, the mesophilous subassociation Quercetum frainetto-cerridis (Rudski 1949) Trinajstić et al. 1996 carpinetosum betuli Rudski 1949 (Art. 30b) [Orig. (Rudski 1949): 'Cyбac. 2. Quercetum confertae-cerris serbicum ca Carpinus betulus'; Typus: Rudski 1949, Tab. 3, rel. 9 - lectotypus hoc loco] still exists, but it should be confined to the stands of Quercetum frainettocerridis, where some mesophilous elements such as Carpinus betulus can take part, but the overall species composition remains xerothermophilous. 


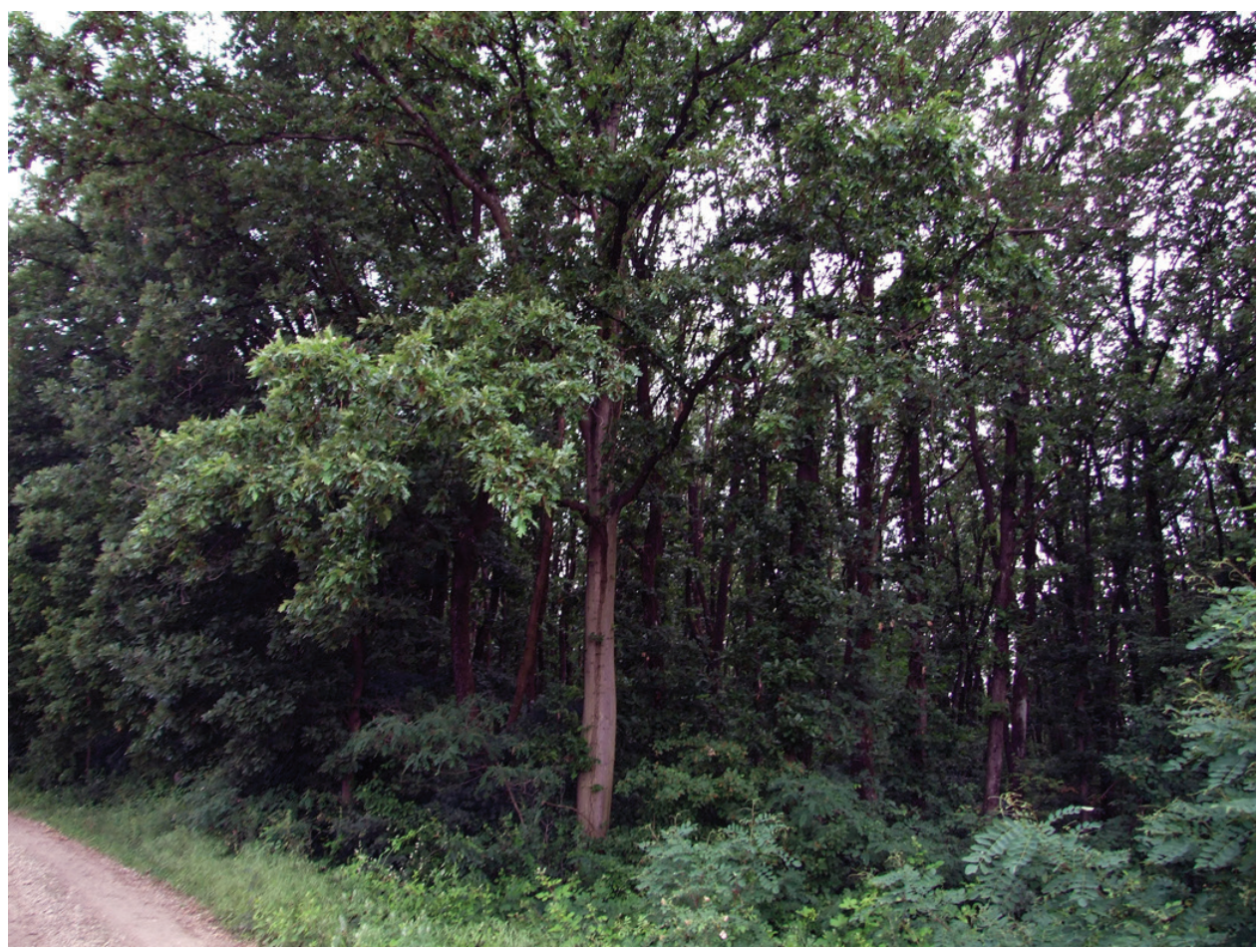

Figure 4. Stand of the association Carpino betuli-Quercetum frainetto in Jankovac (northern Mt. Majevica, B\&H).

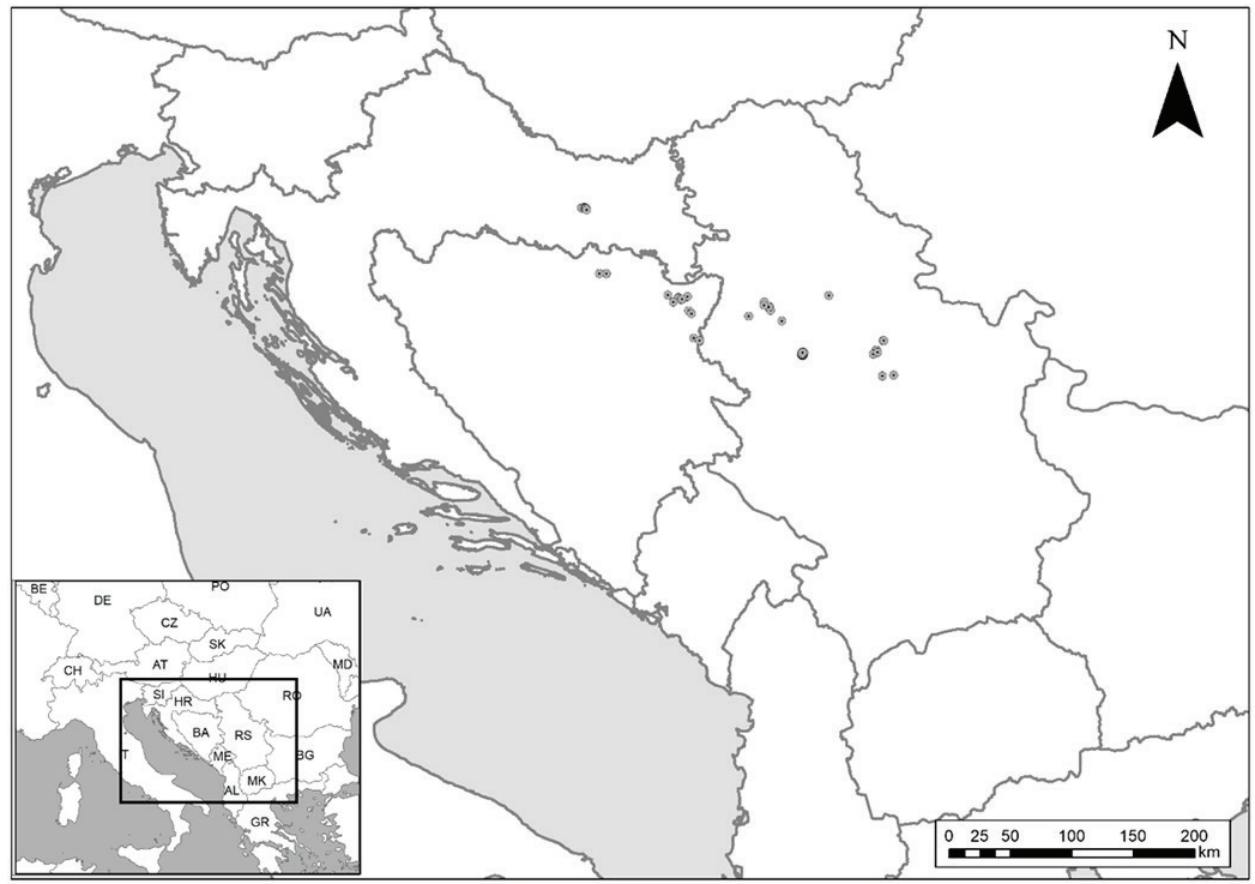

Figure 5. Distribution of the Carpino betuli-Quercetum frainetto researched stands. 
Table 3. Carpino betuli-Quercetum frainetto ass. nov. hoc loco, holotypus: relevé 4 (A - tree layer, B - shrub layer, C - herb layer).

\begin{tabular}{|c|c|c|c|c|c|c|c|c|c|c|}
\hline Relevé number & 1 & 2 & 3 & 4 & 5 & 6 & 7 & 8 & 9 & 10 \\
\hline Country & $\mathrm{BH}$ & $\mathrm{BH}$ & $\mathrm{BH}$ & $\mathrm{BH}$ & $\mathrm{BH}$ & $\mathrm{BH}$ & $\mathrm{BH}$ & RS & RS & $\mathrm{HR}$ \\
\hline Relevé area $\left(\mathrm{m}^{2}\right)$ & 400 & 400 & 900 & 400 & 600 & 400 & 900 & $\mathrm{n} / \mathrm{a}$ & 400 & 200 \\
\hline Altitude $(\mathrm{m})$ & 195 & 140 & 180 & 187 & 150 & 130 & 167 & 190 & 150 & $\mathrm{n} / \mathrm{a}$ \\
\hline Aspect & $S$ & $S$ & $\mathrm{E}$ & SE & NW & $S$ & NW & - & NW & $\mathrm{n} / \mathrm{a}$ \\
\hline Slope (degrees) & 15 & 30 & 5 & 15 & 12 & 27 & 5 & - & 7 & $\mathrm{n} / \mathrm{a}$ \\
\hline Hight of the canopy layer $(\mathrm{m})$ & 27 & 27 & 27 & 30 & 35 & 27 & 30 & $\mathrm{n} / \mathrm{a}$ & 18 & $\mathrm{n} / \mathrm{a}$ \\
\hline Cover total (\%) & 90 & 90 & 90 & 100 & 100 & 100 & 95 & $\mathrm{n} / \mathrm{a}$ & 80 & $\mathrm{n} / \mathrm{a}$ \\
\hline
\end{tabular}

\begin{tabular}{|c|c|c|c|c|c|c|c|c|c|c|c|}
\hline \multicolumn{12}{|c|}{ Characteristic species of the association } \\
\hline Quercus frainetto & $A$ & 5 & 4 & 4 & 4 & 4 & 4 & 3 & 3 & 3 & 4 \\
\hline Quercus frainetto & B & 2 & 1 & 2 & + & . & . & $r$ & 3 & . & 2 \\
\hline Carpinus betulus & A & 2 & 1 & 2 & 2 & 2 & 2 & 2 & 1 & 1 & 1 \\
\hline Carpinus betulus & B & 2 & 2 & 2 & + & 2 & 4 & . & 2 & 1 & 2 \\
\hline Quercus cerris & A & 2 & 3 & 1 & 1 & 1 & 4 & . & 3 & 3 & . \\
\hline Quercus cerris & B & + & $r$ & + & . & . & . & . & 2 & . & . \\
\hline Acer tataricum & B & 1 & 1 & + & 2 & 3 & 2 & 2 & 2 & 2 & + \\
\hline Rosa arvensis & B & 1 & 1 & $\mathrm{r}$ & 1 & 1 & + & . & + & 3 & + \\
\hline Cruciata glabra & C & + & + & 1 & + & . & . & 1 & 1 & 3 & + \\
\hline Galeopsis speciosa & C & + & $r$ & $r$ & $r$ & + & $r$ & $r$ & . & . & 1 \\
\hline \multicolumn{12}{|l|}{ Erythronio-Carpinion } \\
\hline Ruscus aculeatus & B & . & . & 4 & . & + & . & 4 & 3 & 2 & . \\
\hline Tamus communis & C & $r$ & $r$ & 1 & + & + & + & + & . & . & + \\
\hline Epimedium alpinum & C & 2 & . & . & 2 & . & . & 1 & 3 & 1 & . \\
\hline Helleborus odorus & C & . & + & + & . & . & + & . & 1 & 2 & . \\
\hline \multicolumn{12}{|l|}{ Carpino-Fagetea } \\
\hline Acer campestre & A & . & + & . & . & 1 & . & . & 1 & . & . \\
\hline Acer campestre & B & + & 1 & + & 1 & . & + & 1 & 2 & 1 & 1 \\
\hline Ulmus minor & A & . & . & . & . & + & . & . & . & . & . \\
\hline Ulmus minor & B & . & r & . & 1 & 2 & + & . & 2 & 2 & . \\
\hline Crataegus monogyna & B & + & + & $r$ & 1 & + & . & $r$ & 2 & 3 & + \\
\hline Ligustrum vulgare & B & . & 2 & 1 & + & 1 & 3 & 1 & 1 & 3 & 1 \\
\hline Prunus avium & B & 1 & 2 & 2 & 1 & + & + & + & . & . & 2 \\
\hline Rubus hirtus & B & 1 & 1 & 1 & 1 & 4 & 2 & 2 & 2 & . & . \\
\hline Cornus sanguinea & B & $r$ & 2 & . & $r$ & $r$ & 1 & $r$ & . & . & + \\
\hline Pyrus communis ssp. pyraster & B & 2 & . & . & $r$ & + & . & $r$ & . & 1 & + \\
\hline Euonymus europaeus & B & . & + & $r$ & + & + & + & . & . & 2 & . \\
\hline Ruscus hypoglossum & B & + & . & 1 & + & + & . & + & . & . & . \\
\hline Hedera helix & B & $r$ & . & 1 & . & . & . & 1 & 3 & 2 & . \\
\hline Crataegus laevigata & B & . & . & . & + & $r$ & . & . & . & 2 & . \\
\hline Dactylis glomerata & c & 1 & + & . & $r$ & . & + & . & + & 3 & 3 \\
\hline Polygonatum multiflorum & C & + & . & $r$ & + & + & . & + & . & 2 & + \\
\hline Symphytum tuberosum & C & $r$ & $r$ & $r$ & $r$ & $r$ & . & + & . & . & + \\
\hline Viola reichenbachiana & C & r & . & + & . & . & . & . & 1 & . & + \\
\hline Galium schultesii + sylvaticum & C & 2 & + & + & . & + & 1 & . & . & 2 & + \\
\hline Carex sylvatica & C & + & . & . & + & . & + & + & . & . & + \\
\hline Brachypodium sylvaticum & C & r & 1 & . & . & . & 1 & . & . & 2 & + \\
\hline Veronica chamaedrys & C & . & + & r & . & . & . & + & 1 & . & + \\
\hline Lathyrus vernus & C & . & $r$ & + & + & . & $r$ & + & . & . & . \\
\hline Geranium robertianum & C & r & + & . & . & . & + & . & . & . & + \\
\hline Viola hirta & C & . & + & + & $r$ & + & . & + & . & 2 & . \\
\hline
\end{tabular}


Table 3. (continuation) Carpino betuli-Quercetum frainetto ass. nov. hoc loco, holotypus: relevé 4 (A - tree layer, B - shrub layer, C - herb layer).

\begin{tabular}{|c|c|c|c|c|c|c|c|c|c|c|c|}
\hline Stellaria holostea & C & $r$ & . & + & . & . & . & + & . & 2 & . \\
\hline Geum urbanum & C & r & . & . & . & . & r & . & 1 & . & + \\
\hline Glechoma hirsuta & C & . & + & r & . & . & 1 & . & . & . & + \\
\hline Pulmonaria officinalis & C & . & + & . & . & . & r & r & . & . & . \\
\hline \multicolumn{12}{|l|}{ Quercetea pubescentis } \\
\hline Fraxinus ornus & A & . & . & . & . & . & . & . & . & 1 & . \\
\hline Fraxinus ornus & B & 1 & . & $r$ & + & . & . & . & 1 & . & 2 \\
\hline Tilia tomentosa & A & . & . & 1 & . & . & . & . & . & . & . \\
\hline Tilia tomentosa & $\mathrm{B}$ & . & + & 2 & + & . & . & . & 2 & . & . \\
\hline Sorbus torminalis & A & . & . & . & 1 & . & . & . & . & . & . \\
\hline Sorbus torminalis & B & $r$ & . & . & + & + & . & . & . & . & . \\
\hline Melittis melissophyllum & C & + & . & . & $r$ & + & . & $r$ & . & . & . \\
\hline Potentilla micrantha & C & + & . & . & $r$ & . & . & . & . & . & + \\
\hline Clinopodium menthifolium ssp. menthifolium & $\mathrm{C}$ & . & + & . & . & + & + & . & . & . & . \\
\hline Festuca heterophylla & $\mathrm{C}$ & . & + & . & . & . & + & . & . & . & + \\
\hline \multicolumn{12}{|l|}{ Companions } \\
\hline Juniperus communis & B & r & $r$ & . & . & . & + & . & . & . & + \\
\hline Lapsana communis & $\mathrm{C}$ & $r$ & . & . & . & . & . & . & 1 & . & + \\
\hline Alliaria petiolata & $\mathrm{C}$ & . & $r$ & . & . & + & $r$ & . & . & . & . \\
\hline
\end{tabular}

In one or two relevés:

A: Fagus sylvatica 4: 2; Quercus robur 5: +, 9: +; Quercus petraea 7:2;

B: Fagus sylvatica 1: +, 10: +; Cornus mas 2: +, 8: 1; Cytisus nigricans 1: r; Prunus spinosa 4: +; Corylus avellana 5: +; Sambucus nigra 5: +; Fraxinus angustifolia 5: r; Quercus petraea 7: +, 10: +; Malus sylvestris 7: r; Lonicera caprifolium 9: 2; Sorbus domestica 10: +; Rubus discolor 10:

+; Clematis vitalba 10: +; Chamaecytisus supinus 10: +;

C: Luzula forsteri 1: r, 4: +; Physospermum cornubiense 1: r, 5: +; Lactuca muralis 1: r, 10: +; Ajuga reptans 1: r, 10: +; Lathyrus niger 2: +, 5: +; Hieracium sabaudum 2: r, 10: +; Melica nutans 3: +, 7: 1; Dryopteris filix-mas 4: +, 7: r; Cardamine bulbifera 5: 1, 6: $r$; Galium aparine 5: +, 9: 3; Veronica officinalis 8: +, 10: +; Fragaria vesca 8: +, 9: +; Melampyrum nemorosum 1: 2; Hieracium bauhinii 1: +; Solidago virgaurea 1: r; Anthoxanthum odoratum 1: r; Holcus mollis 1: r; Clinopodium vulgare 2: +; Carex divulsa 2: +; Silene nutans 2: +; Primula acaulis 2: r; Verbascum nigrum 2: r; Carex pilosa 4: +; Polystichum setiferum 4: +; Anemone nemorosa 4: r; Pteridium aquilinum 4: $r$; Physalis alkekengi 4: r; Circaea lutetiana 5: +; Calystegia sepium 5: +; Scrophularia nodosa 6: r; Galium odoratum 7: +; Viola riviniana 7: +; Lamiastrum galeobdolon 7: +; Stellaria media 7: +; Polygonatum latifolium 7: r; Asarum europaeum 7: r; Poa trivialis 8: 1; Euphorbia amygdaloides 8: 1; Digitalis lanata 8: +; Campanula patula 8: +; Ficaria verna 9: 3; Aegonychon purpurocaeruleum 9: 2; Euphorbia cyparissias 9: 2; Melica uniflora 9: 2; Lathyrus venetus 9: 1; Vicia sativa 9: +; Vincetoxicum hirundinaria 10: +; Astragalus glycyphyllos 10: +; Carex flacca 10: +; Trifolium medium 10: +; Viola alba 10: +; Moehringia trinervia 10: +; Galium sp. 10: 2; Melampyrum sylvaticum 10: 1; Helleborus croaticus 10: 1; Prunella grandiflora 10: 1; Genista tinctoria 10: 1;

Details of relevés (indicated in the following order: relevé number, date (year/month/day), description of locality, country, longitude, latitude, source (if applicable):

1) 2011/06/30, Tutnjevac, Granik (northern Majevica), B\&H, 18.955133, 44.737049; 2) 2011/07/01, Dugo polje, Betnja (Modriča), B\&H, 18.174561, 44.928112; 3) 2011/06/30, Bobetino brdo (northern Majevica), B\&H, 18.916891, 44.747484; 4) 2011/06/30, Tutnjevac, Granik (northern Majevica), B\&H, 18.953569, 44.737086; 5) 2010/05/28, Jankovac (northern Majevica), B\&H, 19.008045, 44.755608; 6) 2011/07/01, Dugo polje, Betnja (Modriča), B\&H, 18.17413, 44.927926; 7) 2011/06/30, Bobetino brdo (northern Majevica), B\&H, 18.915362, 44.746641; 8), Šumski kompleks Bogovađa, Serbia, 20.16802, 44.32401, (Glišić 1968, tab. 1, rel. 13); 9) , Posavina, Kozadra, Serbia, 19.633156, 44.603326, (Vukićević 1959, tab. 2, rel. 6); 10) southern Krndiia. Croatia, 17.9651, 45.40494 (Trinaistić et al. 1996, tab. 1, rel. 8).

\section{DISCUSSION}

Despite the considerable number of described communities dominated by Hungarian oak on a relatively small distribution area of this species, until recently their syntaxonomy seemed settled inside two alliances of Quercetalia pubescenti-petraeae. In Italy, these communities are classified into Crataego laevigatae-Quercion cerridis (Blasi et al. 2004, Landucci et al. 2012), while in Balkan part of the distribution area they have been traditionally classified inside Quercion confertae (Lakušić et al. 1978, Jovanović et al. 1986, Kojić et al. 1998, Bergmeier and Dimopoulos 2008,
Kavgaci et al. 2010, Borhidi et al. 2012, Vukelić 2012, Tomić and Rakonjac 2013, Indreica 2015, Škvorc et al. 2017).

However, EuroVegChecklist (Mucina et al. 2016) recently reintroduced the old concept of classification of southern Balkan thermophilous deciduous oak forests on slightly acidic deep soils in the distinct alliance Melitto albidae-Quercion (first proposed by Barbero and Quézel (1976)) which was partly supported and further elaborated by Di Pietro et al. (2019). Still, there is no general agreement about its syntaxonomic independence from the Quercion confertae (Bergmeier and Dimopoulos 2008, Çoban and Willner 2019). 
Meanwhile, in Bulgaria, Tzonev et al. (2019) classified Quercetum frainetto-cerridis and Hedero helicis-Quercetum cerridis in the Quercion confertae, while Rusco aculeatiQuercetum frainetto, Symphyto ottomani-Quercetum frainetto and the community of Quercus frainetto and Hypericum cerastoides have been assigned to Quercion petraeo-cerridis. More importantly, authors emphasized that Hedero helicis-Quercetum cerridis is a transitional association towards Erythronio-Carpinion, and stated that ecologically similar associations from Italy (Erythronio-Quercetum cerridis Biondi et al. 2002 and Listero ovatae-Quercetum cerridis Di Pietro \& Tondi 2005), with similar intermediate features towards Quercetalia pubescenti-petraeae have been assigned to Erythronio-Carpinion. They also pointed to similar syntaxa from Romania and Serbia, i.e., Potentillo micranthaeQuercetum dalechampii Horvat 1981, Carpino betuliQuercetum frainetto-cerris (Rudski 1940) 1949 B. Jovanović 1968, and Robori-Quercetum frainetto-cerris (Slavnić 1952) B. Jovanović et Z. Tomić 1978.

Furthermore, the present study revealed that mesophilous Hungarian oak stands from north-western margin of its distribution area should be classified into ErythronioCarpinion, while there is at least one association dominated by Hungarian oak that belongs to Carpinion orientalis (i.e., Carpino orientalis-Quercetum frainetto (Rizovski 1978) Matevski et al. 2008).

In addition to syntaxonomical inconsistencies, different interpretations of biogeography of Hungarian oak communities in Balkan Peninsula have also been provided. While communities of Quercion confertae have been traditionally considered as zonal for the continental bioclimatic zone of Balkans (Horvat 1954, 1958, Horvat et al. 1974), soil and topography are more likely to influence the occurrence of Quercion confertae and Carpinion orientalis in submediterranean mainland Greece according to Bergmeier and Dimopoulos (2008). Hence, they are not suitable to define the bioclimatic zone in the southern Balkans. A similar issue was raised on the opposite side of Quercion confertae distribution area, in the north-western Serbia, where Jovanović (1967) argued that Hungarian oak community common for the area (Quercetum frainetto-cerris hieracietosum) is not representative of macro-climatic conditions and therefore, contrary to Hungarian oak communities of eastern and southeastern Serbia, not zonal. On the other hand, Stupar and Čarni (2017) demonstrated that the variation in floristic composition between zonal forests of Aremonio-Fagion, Erythronio-Carpinion, Quercion confertae and Carpinion orientalis in $\mathrm{B} \& \mathrm{H}$ is completely macro-climatically driven and that there is no influence of soil condition, which indicates that Quercetum frainetto-cerridis is zonal in eastern B\&H.

All these different and sometimes contradictory findings complicate the question of syntaxonomy of Quercion confertae and in particular its central association Quercetum frainettocerridis. While clusters 4 (the type community originally published by Rudski (1949)) and 5 (southern communities from Kosovo and Metohija and North Macedonia) are fairly well defined by a few diagnostic species of Balkan character: Galium pseudaristatum, Physospermum cornubiense, Lathyrus laxiflorus and Trifolium pignantii (the latter two important only for southern clusters 5 and 6), cluster 3 , which has the most relevés in the present dataset, is quite poorly characterized by these same species (Table 1). The reason behind this may be that the majority of the relevés in cluster 3 are not representative due to the structural degradation of Hungarian oak forest stands or that these communities are just transitional between the "real" Quercion confertae, Quercion petraeo-cerridis, Carpinion orientalis and Quercion petraeae. On the other hand, when studied together with other thermophilous deciduous forests of the western and central Balkans, Hungarian oak forests from Serbia and eastern B\&H group together with Turkey oak forests on deep and slightly acidic soil over the limestone in the western B\&H (which completely lack the Balkan element) (Stupar et al. 2016). This means that if we accept the concept of coexistence of the two separate and vicariant alliances of Hungarian oak in the Balkan Peninsula as suggested by Mucina et al. (2016) and Di Pietro et al. (2019), then the southern Balkan Melitto albidae-Quercion would have the diagnostic species which are mainly with the southern Balkan distribution, while the mainly non-frequent appearance of Balkan element (Galium pseudaristatum and Physospermum cornubiense) in northern-central Balkans Quercion confertae would not be considered as important for the alliance. This would alleviate the potential redefinition of the circumscription of alliance Quercion confertae in the scope of thermophilous deciduous forests of Southeastern Europe. In any case, the syntaxonomic issues of Quercion confertae of the Balkan Peninsula deserve more attention in future studies.

\section{CONCLUSIONS}

The results of the present analysis support the hypothesis that mesophilous Hungarian oak communities from the north-western margin of its range do not belong to the Balkan thermophiolous oak forests on slightly acidic deep soils (Quercion confertae), but rather to the mesophilous oak-hornbeam forests on deep nutrient-rich soils of the Balkans and Northern Italy (Erythronio-Carpinion). The new mesophilous association Carpino betuli-Quercetum frainetto ass. nova hoc loco was described and assigned to ErythronioCarpinion. The results also indicate that syntaxonomy of Hungarian oak forests on the Balkan Peninsula is far from being settled. Some possible solutions that require further investigation were introduced.

\section{Funding}

This research received no external funding.

\section{Acknowledgments}

Author would like to thank to Andraž Čarni for advices concerning syntaxonomic nomenclature. Thanks are also due to anonymous referees for valuable comments and suggestions that have improved the first version of the manuscript.

\section{Conflicts of Interest}

The author declares no conflict of interest.

\section{Suplementary Materials}

Suplementary File 1. Sources of data use for the analysis. Suplementary File 2. Full synoptic table. 


\section{REFERENCES}

Barbero M, Quézel P, 1976. Les groupements forestiers de Grèce Centro-Méridionale. Ecol Mediterr 2(1): 3-86. https://doi. org/10.3406/ecmed.1976.920.

Bergmeier E, Dimopoulos P, 2008. Identifying plant communities of thermophilous deciduous forest in Greece: Species composition, distribution, ecology and syntaxonomy. Plant Biosyst 142(2): 228-254. doi: https://doi. org/10.1080/11263500802150357.

Blasi C, Di Pietro R, Filesi L, 2004. Syntaxonomical revision of Quercetalia pubescenti-petraeae in the Italian Peninsula. Fitosociologia 41(1): 87-164.

Borhidi A, Kevey B, Lendvai G, 2012. Plant communities of Hungary. Akadémiai Kiadó, Hungary, 526 p.

Braun-Blanquet J, 1964. Pflanzensoziologie, Grundzüge der Vegetationskunde. 3rd ed. Springer Verlag, Netherlands, 865 p.

Chytrý M, Tichý L, Holt J, Botta-Dukát Z, 2002. Determination of diagnostic species with statistical fidelity measures. J Veg Sci 13(1): 79-90. https://doi.org/10.1111/i.1654-1103.2002. tb02025.x.

Çoban S, Willner W, 2019. Numerical classification of the forest vegetation in the Western Euxine Region of Turkey. Phytocoenologia 49(1): 71-106. https://doi.org/10.1127/ phyto/2018/0274.

Delijanić I, Radičević D, Sokolović-llić G, Ivanović D, Milošević S, Seničar E, 1964. Klimatska rejonizacija Jugoslavije i tabelarni prikaz temperaturnih i pluviometrijskih karakteristika klimatskih reona Jugoslavije. Jugosl Poljopr Šumar Cent Beogr : 121-138.

Di Pietro R, Fortini P, Ciaschetti G, Rosati L, Viciani D, Terzi M, 2019. A revision of the syntaxonomy of the Apennine-Balkan Quercus cerris and Q. frainetto forests and correct application of the name Melittio-Quercion frainetto. Plant Biosyst 0(0): 1-23. doi: https://doi.org/10.1080/11263504.2019.1701127

Euro+Med Euro+Med PlantBase - the Information Resource for Euro-Mediterranean Plant Diversity, 2006. Available online: http://ww2.bgbm.org/EuroPlusMed/query.asp (Accessed 12 October 2015)

Fukarek P, Fabijanić B, Janjić N, 1974. Nova nalazišta sladuna (Quercus conferta Kit.) u Bosni i Hercegovini. In: Zbornik radova sa Simpozijuma povodom 100. godišnjice prve Jugoslovenske dendrologije Josifa Pančića. Simpozijum povodom 100. godišnjice prve Jugoslovenske dendrologije Josifa Pančića, Beograd, Srpska akademija nauka i umetnosti, pp 69-83.

Glišić M, 1968. Šumske fitocenoze šumskog kompleksa "Bogovađa." Zb Rad Instituta Za Šumar Drv Ind Beogr 8: 29-64.

Hennekens SM, Schaminée JHJ, 2001. TURBOVEG, a comprehensive data base management system for vegetation data. J Veg Sci 12(4): 589-591. https://doi. org/10.2307/3237010.

Horvat I, 1954. Pflanzengeographische Gliederung Südosteuropas. Vegetatio 5/6(1): 434-447.

Horvat I, 1958. Laubwerfende Eichenzonen Südosteuropas in pflanzensoziologischer, klimatischer und bodenkundlicher Betrachtung. Angew Pflanzensoziol 15: 50-62.

Horvat I, Glavač V, Ellenberg H, 1974. Vegetation Südosteuropas. Geobotanica selecta. Gustav Fischer Verlag, 767 p.

Indreica A, 2015. Classe Quercetea pubescentis Doing-Kraft ex Scamoni et Passarge 1959. In: Coldea G (ed) Les associations vegetales de Roumanie. Tome 3. Les associations forestrieres et arbustives. Presa Universitară Clujeană \& Accent, pp 126185.

Jovanović B, 1967. Neke šumske fitocenoze severozapadne Srbije. Zb Rad Instituta Za Šumar Drv Ind Beogr 6: 19-72.

Jovanović B, Dunjić R, 1951. Prilog poznavanju fitocenoza hrastovih šuma Jasenice i okoline Beograda. Zb Rad Inst Ekol Biogeogr Srp Akad Nauk 2: 203-230.
Jovanović $B$, Lakušić $R$, Rizovski $R$, Trinajstić I, Zupančič $M$, 1986. Prodromus phytocoenosum Jugoslaviae ad mappam vegetationis $m$ 1:200 000. Naučno veće vegetacijske karte Jugoslavije, $46 \mathrm{p}$.

Kavgaci A, Čarni A, Tecimen B, Ozalp G, 2010. Diversity and ecological differentiation of oak forests in NW Thrace (Turkey). Arch Biol Sci Belgrade 62(3): 705-718. https://doi. org/10.2298/ABS1003705K.

Kojić M, Popović R, Karadžić, Branko, 1998. Sintaksonomski pregled vegetacije Srbije. Institut za biološka istraživanja "Siniša Stanković," 218 p.

Lakušić R, Pavlović D, Abadžić S, Grgić P, 1978. Prodromus biljnih zajednica Bosne i Hercegovine. God Biološkog Instituta Univ U Sarajevu Poseb lzd 30: 5-88.

Landucci F, Acosta ATR, Agrillo E, Attorre F, Biondi E, Cambria VE, Chiarucci A, Del Vico E, De Sanctis M, Facioni L, Geri F, Gigante $D$, Guarino R, Landi S, Lucarini D, Panfili E, Pesaresi S, Prisco I, Rosati L, Spada F, 2012. VegItaly: The Italian collaborative project for a national vegetation database. Plant Biosyst 146(4): 756-763. https://doi.org/10.1080/11263504.2012.74 $\underline{0093}$.

Matevski V, Čarni A, Kostadinovski M, Košir P, Šilc U, Zelnik I, 2008. Flora and vegetation of the Macedonian steppe. Biološki inštitut Jovana Hadžija ZRC SAZU, $96 \mathrm{p}$.

Mucina L, Bültmann H, Dierßen K, Theurillat JP, Raus T, Čarni A, Šumberová K, Willner W, Dengler J, García RG, Chytrý M, Hájek $M$, Di Pietro R, lakushenko D, Pallas J, Daniëls FJA, Bergmeier E, Santos Guerra A, Ermakov N, Valachovič M, Schaminée JHJ, Lysenko T, Didukh YP, Pignatti S, Rodwell JS, Capelo J, Weber HE, Solomeshch A, Dimopoulos P, Aguiar C, Hennekens SM, Tichý L, 2016. Vegetation of Europe: hierarchical floristic classification system of vascular plant, bryophyte, lichen, and algal communities. Appl Veg Sci 19: 3-264. https://doi. org/10.1111/avsc.12257.

PignattiS, Menegoni P, PietrosantiS, 2005. Valori di bioindicazione delle piante vascolari della flora d'Italia. Braun-Blanquetia 39: 1-97.

Rivas-Martínez S, Penas A, Díaz TE 2004. Biogeographic map of Europe. Cartographic Service, University of León, León, Spain.

Rizovski R, 1972. Šumite na dabot ploskač (Quercus farnetto Ten.) vo južnite kraišta na SR Makedonija. PhD Thesis, Ss. Cyril and Methodius University in Skopje, Skopje, Macedonia.

Rudski I, 1949. Tipovi lišćarskih šuma jugoistočnog dela Šumadije. Prir Muz Srp Zemlje Beogr 25: 1-67.

Škvorc Ž, Jasprica N, Alegro A, Kovačić S, Franjić J, Krstonošić D, Vraneša A, Čarni A, 2017. Vegetation of Croatia: Phytosociological classification of the high-rank syntaxa. Acta Bot Croat 76(2): 200-224. https://doi.org/10.1515/ botcro-2017-0014.

Stajić S, Rakonjac L, Čokeša V, 2008. Phytocenological characteristics of Hungarian oak and Turkey oak with hornbeam forest (Carpino betuli-Quercetum farnetto-cerris) in the area of Bogovađa. Sustain For 57-58: 104-114.

Stefanović V, 1988. Cenohorološki odnosi hrasta sladuna (Quercus frainetto Ten.) na sjeverozapadnoj granici areala u Bosni. In: Zbornik referata naučnog skupa "Minerali, stijene, izumrli i živi svijet BiH, Sarajevo, 7-8. oktobar 1988." Minerali, stijene, izumrli i živi svijet BiH, Sarajevo, 7-8. oktobar 1988., Sarajevo, BA, Zemaljski muzej Bosne i Hercegovine, pp 375385.

Stupar V, Brujić J, Škvorc Ž, Čarni A, 2016. Vegetation types of thermophilous deciduous forests (Quercetea pubescentis) in the Western Balkans. Phytocoenologia 46(1): 49-68. https:// doi.org/10.1127/phyto/2016/0052.

Stupar V, Čarni A, 2017. Ecological, floristic and functional analysis of zonal forest vegetation in Bosnia and Herzegovina. Acta Bot Croat 76(1): 15-26. https://doi.org/10.1515/ botcro-2016-0041. 
Stupar V, Milanović Đ, Brujić J, Čarni A, 2015. Formalized classification and nomenclatural revision of thermophilous deciduous forests (Quercetalia pubescentis) of Bosnia and Herzegovina. Tuexenia 35: 85-130. https://doi. org/10.14471/2015.35.016.

Theurillat JP, Willner W, Fernández-González F, Bültmann H, Čarni A, Gigante D, Mucina L, Weber H, 2020. International Code of Phytosociological Nomenclature. 4th edition. Appl Veg Sci. https://doi.org/10.1111/avsc.12491.

Tichý L, 2002. JUICE, software for vegetation classification. J Veg Sci13(3): 451-453. https://doi.org/10.1111/j.1654-1103.2002. tb02069.x.

Tomić Z, Rakonjac L, 2013. Šumske fitocenoze Srbije: Priručnik za šumare, ekologe i biologe. Univerzitet Singidunum, Fakultet za primenjenu ekologiju Futura i Institut za šumarstvo, Belgrade, Serbia, $177 \mathrm{p}$.

Trinajstić I, Franjić J, Samardžić J, Samardžić I, 1996. Fitocenološke značajke šuma sladuna i cera (as. Quercetum frainetto-ceris Rudski 1949) u Slavoniji (Hrvatska). Šumar List 120(7-8): 299306.
Tzonev R, Dimitrov M, Gussev C, Pachedjieva K, Gogushev G, Apostolova-Stoyanova N, Nikolov I, Alexandrova A, Glogov P, 2019. Phytosociological classification of the thermophilous oak forests in Bulgaria: new interpretations and gaps in knowledge. Phytocoenologia 49(4): 369-391. https://doi. org/10.1127/phyto/2019/0296.

Velić I, Velić J, 1983. Petrografska karta SFR Jugoslavije. Šumarska Enciklopedija. 2nd ed. Jugoslavenski leksikografski zavod, p 624.

Vukelić J, 2012. Šumska vegetacija Hrvatske. Šumarski fakultet, Sveučilište u Zagrebu, DZZP, Zagreb, Croatia 403 p.

Vukićević E, 1959. Šumske fitocenoze u neplavljenom području Posavine. Glas Šumar Fak 16: 381-399.

Zelený D, Schaffers AP, 2012. Too good to be true: pitfalls of using mean Ellenberg indicator values in vegetation analyses. J Veg Sci 23(3): 419-431. doi: https://doi.org/10.1111/i.16541103.2011.01366.x. 